https://doi.org/10.18485/dpls_pld.2020.6.ch6

371.3::003.332.5

Mina Suknović

University of Belgrade

\title{
L2 READING SKILL ACQUISITION IN NON-LITERATE ADULT NATIVE SPEAKERS OF ARABIC
}

\begin{abstract}
Reading is a complex skill requiring a range of cognitive and metalinguistic processes. This paper presents an overview of literacy definitions and bottom-up and top-down processes in reading and emphasises the importance of phonological awareness. It describes the outcomes of a study that re-examines the efficiency of whole language and phonics based curriculum of an English literacy course for non-literate Arabic natives. The purpose of the paper is to underscore the relevant processes and techniques crucial for developing reading skill, which are to be applied in L2 literacy classrooms, in order to enable and empower students to use a language as a tool which will give them an opportunity to successfully integrate into society as functionally literate individuals.
\end{abstract}

Key words: reading skill, L2 literacy, phonological awareness, bottom-up and top-down processes, phonics, whole language approach

\section{Introduction}

In today's world of high mobility we are facing an increased need for cultural mediation and social integration where a language is a means to achieve this, but often an obstacle as well. Moreover, there is an attitude in post-industrial countries that immigrants are the main source of economic growth which rests on the misguided assumption that a typical immigrant has spoken and written second language skills (Young-Scholten \& Strom 2006: 45). Worldwide statistics on literacy, however, show that 20 million refugees (Oxford Brookes University Development and Forced Migration Research Unit) and 861 million adults are unable to read in their native language or any other language (UN Literacy Decade Project). Bearing in 
mind the fact that almost all the countries which usually take in immigrants and refugees are hyperliterate societies, these numbers are even more alarming. Therefore, a clear need for developing literacy programs has arisen, especially the ones focusing on writing and reading in the language of the new community.

Researchers from a variety of disciplines including cognitive linguistics, cognitive and developmental psychology, and education, have been active in research on reading. This mix reflects the fact that the study of reading is both theoretically and practically important. Reading is a domain in which experimental psychologists and linguists study fundamental questions such as how knowledge and experience affect perception (Treiman 2017: 617). Research findings have implications for key social issues, such as cultural and social integration. It is no wonder, then, that a large amount of research has been carried out on reading. However, very little research has been conducted on the development of L2 reading skills in L1 non-literates.

Whereas speaking and listening are natural to all human beings and these skills are often referred to as "primary" linguistic activities (Klassen \& Burnaby 1993:378), reading and writing are products of the development of civilised cultures. Therefore, a secondary linguistic activity, such as reading, is "parasitic" on primary activities (ibid.) and requires a certain degree of metalinguistic awareness. There has been a general consensus on the idea that metalinguistic awareness, phonological awareness in particular, facilitates reading acquisition. On the other hand, having at least beginner reading and writing skills engenders the development of phonological awareness in return. For this reason, it is important to develop programs that will simultaneously develop both receptive and productive skills, along with metalinguistic awareness. In order to do so, several factors have to be taken into consideration: cognitive processes (bottom-up and top-down), sociocultural differences, (un)familiarity of classroom surroundings, affective state, existence of traumas etc.

The purpose of this paper is to present an overview of the aforementioned cognitive processes involved when reading and the implications they might have when acquiring L2 reading skills for the very first time in order to develop appropriate strategies for teaching adult L1 non-literates who are gaining literacy skills in L2. Moreover, the paper re-examines the efficiency of two main approaches to beginner reading phonics and whole language approach - using the results of a small-scale 
study that followed two groups of non-literate Arabic native speakers, students of L2 English class.

\section{First Language Literacy}

The claim that a native language affects L2 acquisition in numerous ways has been empirically confirmed. Therefore, it is quite logical to conclude that literacy in native language has great impact on gaining L2 skills. A modest body of research in cognitive sciences was interested in how complete or partial absence of literacy affects the way adults comprehend, reproduce and manipulate language orally and in writing. Research has shown that even the lowest level of literacy can contribute to faster progress (Bigelow \& Watson 2012; Gunn 2003).

Depending on their first language literacy background, six types of literacy learners have been identified: pre-literate, non-literate, semiliterate, non-alphabet literate, non-Roman alphabet literate, and Roman alphabet literate ${ }^{1}$ (Gardner et al. 1996:2). Since the first three are related to speakers of limited or no literacy at all, only these groups will be taken into consideration.

Pre-literate learners come from cultures where literacy plays little or no part in communication or the written language of the community is not written or it is being developed (e.g., the Bantu of Somalia and the Dinka of Sudan). They need to be taught that written language is a system, that words are a form of symbolic representation, that writing direction and word position are set etc. Since they had little or no exposure to written language, they are often unaware of its importance and purpose (Burt el al. 2003: 8). Moreover, it can be challenging for them to accept their new role in hyperliterate society. It is worth noting that their progress is quite slow and they require frequent repetition.

Non-literate learners come from cultures where literacy is more common. However, due to their socio-economic or political status, they have not had sufficient access to literacy (Burt et al. 2003: 9). For instance, women from rural parts of Northern Africa may not have gained literacy skills in their native Arabic because of the lack of formal education due to their sociocultural status within their family or community. Despite not having learned to read and write, non-literates have usually been exposed

\footnotetext{
1 There has not been a consensus among researchers in the field of L2 literacy acquisition on the terminology. Terms are used quite freely and are subjected to various interpretations. Therefore it is important to provide definitions and differentiate between the terms used in the paper.
} 
to written discourse and may have a greater awareness of the value and uses of literacy than pre-literate learners.

Semi-literate learners have had an access to literacy in their native culture, but because of their socio-economic status or political or educational situation, they have not achieved a high level of literacy in their native language (ibid). These adults may have had disrupted schooling or left school at a young age for economic or political reasons (e.g., as have many refugees from the Middle East or the Horn of Africa in the last 20 years), or they may have lived in a foreign country and developed certain level of oral L2 proficiency but not literacy. Although they do have some literacy skills in their mother tongue, it is not enough for them to have confidence in tackling English literacy (Gardner et al. 1996:2). Semiliterates along with non-literates may be reluctant to disclose their limited literacy background in class (ibid.).

All three subgroups of illiterates have a daunting task ahead and face a number of difficulties while attending L2 literacy classes. They have no or very little metacognitive knowledge from the first language for the positive transfer to occur. Unlike a beginning-level native-languageliterate learner who can read L2 text without comprehending it, a nonliterate learner at the same level of oral proficiency can do neither. With no L1 metalinguistic skills to transfer and little L2 linguistic competence upon which the development of metalinguistic awareness can 'piggyback' (Gombert 1992: 24), such a learner faces great hurdles on the road to literacy. In addition, written materials are of limited use in these classes and the students experience difficulties in retaining content covered in class due to not being able to take notes and revise the work later on. Another issue is that they have no mental lexicon to draw on from when learning to read. Learners need to read in order to gain vocabulary knowledge, but they need vocabulary knowledge in order to read. This dual interaction is the basis of the "beginner's paradox" (Coady 1997: 229).

Because of their limited educational experiences, they may feel intimidated about learning L2 in classrooms. Moreover, they might not be familiar with the social conventions regarding appropriate formal schooling behaviour. At the same time, they are often highly motivated to learn, and given the support from their family members or the community, they will make progress.

It is important to understand literacy in a sociocultural context since this understanding can contribute to a more complete understanding of 
literacy across cultures and contexts (Reder \& Davila 2005: 172). Due to a very specific demographic structure of L2 literacy classes, drop-out rate is often very high (Benseman 2012; Condelli \& Wrigley 2008; Gunn 2003). Majority of students who attend these classes are usually women who often do not come across support in their families and communities because of their socio-economic status. Woman's role in these societies is often traditionally determined and they often lack encouragement and support needed, and have to drop out because they have to take care of children, cook etc.

Generally all students who attend literacy courses need opportunities to increase their self-confidence in educational situations and to develop positive images of themselves as readers and writers (Goldberg 1997; Strucker 1997) and to eventually become participants in literate society.

\section{Bottom-up and top-down processes in reading}

Psychologists have distinguished two kinds of processes that are involved not only in reading but also in other cognitive tasks - bottom-up and top-down. Theories about cognitive processes put different emphasis on them. One of the theories that stresses the importance of bottomup processes proposed by Gough (1972) claims that readers deal with letters and words in a relatively complete and systematic fashion. When applying bottom-up process the reader arrives at the meaning by moving from letters to words to phrases and sentences. On the other hand, theories that emphasise top-down processes propose that readers form hypotheses about which words they will encounter and based on the visual information intake, test those hypotheses. The reader derives the meaning primarily from predictions about the text and background knowledge (Burt et al. 2003: 24). In other words, reading is a psycholinguistic guessing game (Goodman 1967). Understanding a text requires activating and using schema, which are related to cultural knowledge often not shared by the learners and speakers of the language that is being acquired.

To put these theories in practice, suppose that someone has just read:

Tomorrow I have to get up earlier than usually, so I mustn't forget to set the...

According to a top-down view the reader based on the context and background knowledge forms a hypothesis that the next word is alarm 
and searches visual confirmation in the form of a letter $a$. If the word does start with the letter $a$, the reader moves on, without actually reading the remaining letters. On the contrary, bottom-up processing theories claim that the reader processes all the letters in the word, regardless of its predictability.

These two processes often work together to ensure rapid and accurate performance and form so-called "interactive model" (Burt et al. 2003: 25). According to it, most of the processes that fluent readers use are bottom-up and automatic which studies on how people's eyes move when reading confirmed (e.g. Rayner et al. 2002). However, when they are not enough for comprehension, top-down processes such as getting meaning form context and using syntax cues can be activated. Most researches nowadays agree that in fact interactive models are applied (Treiman 2018; Burt et al. 2003; Grabe \& Stoller 2002).

\section{Whole language approach and Phonics}

There are two main approaches that have been put forward when learners are taught to read for the first time. The whole language approach is based on the notion that top-down processes play an important part in acquiring reading skill. Teachers who use this approach put the emphasis on the meaning of the words and the purpose and function of written language, not the individual sounds and letters (Benseman 2010: 15). Activities typically include reading stories, using "real life" materials (e.g. leaflets, notices, forms, menus etc.), teaching key sight words (sight word knowledge is ability to recognize words without having to sound them out), using pictures to figure out the meaning etc. Students are immersed in the language and they are expected to "pick up" the language without systematic instruction. On the other hand, the phonics approach stresses the importance of bottom-up processes with activities such as minimal pairs, matching letters to sounds, grouping words with the same first letter or sound, counting syllables etc. In this view, learning to read and write is quite different from learning to understand and talk and requires explicit instruction (Treiman 2018: 11). This approach focuses on individual letters and sounds, repetition and practice. Unlike when using the whole language approach, materials are not primarily chosen based on the content and application, but most importantly, the words have to be easy to decode. 
Across a large number of studies, programs that include attention to phonics tend to yield better results than programs that do not (Ehri et al 2001). The explanation for this can lie in the fact that phonics programs develop phonological awareness simultaneously. There has been a considerable body of research that emphasise the value of the role phonological awareness has in successful decoding (Bigelow \& Watson 2012; Condelli \& Wrigley 2008; August 2003; Kodzopeljic 1996).

\section{Methodology}

\section{Participants}

For this small scale study 7 participants were selected and put into two groups. All speakers were adults, from North African countries, native speakers of Arabic with very little or no formal education (see Table 1). They all came to Serbia legally, following members of their family (husbands or children) who came to study. Before they started the course, they had been given a personal information form in Arabic that they completed with the help of an interpreter since they were unable to read or write in their mother tongue. Only two of the participants had limited formal education that was interrupted due to personal reasons. Student 7 (S7) had to leave school after the death of his father and work on the family's farm. The other student's family (S3) decided that she had no use from schooling. Although they had limited experience of formal education, it is worth noting that it did give them slight initial advantage (e.g. they were more comfortable in classroom environment). The fact that there are more women in this study is consistent with other studies and research which dealt with non-literates and a testimony to the fact that much less attention is paid to female education all over the world (Benseman 2012; Gunn 2003; Statistical office of the republic of Serbia 2001). All the participants showed enthusiasm and were eager to learn and participate in the study.

\begin{tabular}{|c|l|l|l|c|}
\hline Student No. & Ethnicity & Gender & Occupation & Formal \\
\hline S1 & Algerian & Female, 22 & Housewife & 0 \\
\hline S2 & Egyptian & Male, 43 & Farmer & 0 \\
\hline S3 & Libyan & Female, 36 & Housewife & 1 \\
\hline S4 & Libyan & Female, 48 & Housewife & 0 \\
\hline S5 & Libyan & Female, 39 & Housewife & 0 \\
\hline S6 & Libyan & Female, 41 & Housewife & 0 \\
\hline S7 & Libyan & Male, 46 & Water driller & 1.5 \\
\hline
\end{tabular}

Table 1 - Participants 


\section{Procedures and language assessment tools}

The students were randomly split into two groups. Both groups had the same teacher and had classes $(90 \mathrm{~min})$ four times a week. The groups had classes for three months, after which they were given a test and they participated in a structured interview in their native language with the presence of an interpreter. The first group (3 students) was taught by using a curriculum that was based on the whole language approach whereas the second one (4 students) had a phonics-based curriculum. After the 3-month period, they were tested using a three-part test:

- Section A: Matching words and pictures

- Section B: Reading familiar and unfamiliar words

- Section C: Reading simple questions (up to 5 words) and answering orally

In Section A of the test they had to read familiar words (words already covered in class) silently and match them to the pictures - twelve pairs, two extra words. The accuracy in this part was measured based on the number of correctly matched pairs. In Section B, they were to read aloud a set of 10 familiar and 10 unfamiliar monosyllabic words. If they pronounced targeted phonemes correctly, the word was considered to have been pronounced correctly. The final part comprised of 6 simple questions that they had to read silently and then answer. They were given points if their answer matched the question and conveyed the message. Grammar or pronunciation accuracy were of no relevance. The goal of the test was to test comprehension in the first and third task and word decoding in the second. Later, interviews were conducted one on one with an interpreter, using a prepared set of questions. The goal of the interview was to examine learners' attitudes towards the curriculum and classes - usefulness of materials, personal sense of progress, attitudes towards the importance to read, motivation, level of support they got from family members and issues with the curriculum.

\section{Results and Discussion}

Although the study is based on a small sample and the number of variables is large, the results are consistent with the experience of the author and many ESL professionals who work with learners at various literacy levels. 
In Section A of the test where participants matched pictures and words both groups exceeded expectations. The WL (whole language) group had an accuracy rate of $85 \%$ compared to the $\mathrm{PH}$ (phonics) group which had 78\% (see Table 2). This is quite understandable considering the great immersion of WL group. They were simply much more exposed to the written language in general, especially to key sight words.

Section B of the test had two tasks. In the first task where they had to read familiar words, PH group outperformed the other. The difference was much greater in the second task with unfamiliar words. Since this section of the test relied greatly on the knowledge of phonemes and bottom-up process, it is no surprise that the group that had considerable training in phonics outperformed. However, both groups performed quite poorly in the second task, mainly due to the fact that they had only had three months of instruction and not sufficient practice or exposure.

In the final section of the test where they answered simple and common questions we can notice a striking difference. This can be explained by the fact that the WL group made a lot of mistakes based on wrong assumptions (top-down process). They would recognise the first couple of words and assume the second part of the questions, or they would see the first letter or two and assume what the word was. The questions in the test were similar to those frequently done in class, but with some alternations (e.g. How old are your children? instead of How old are you?), and required both processes, especially bottom-up. The $\mathrm{PH}$ group relied more on decoding and trying to recognise and connect phonemes than guessing.

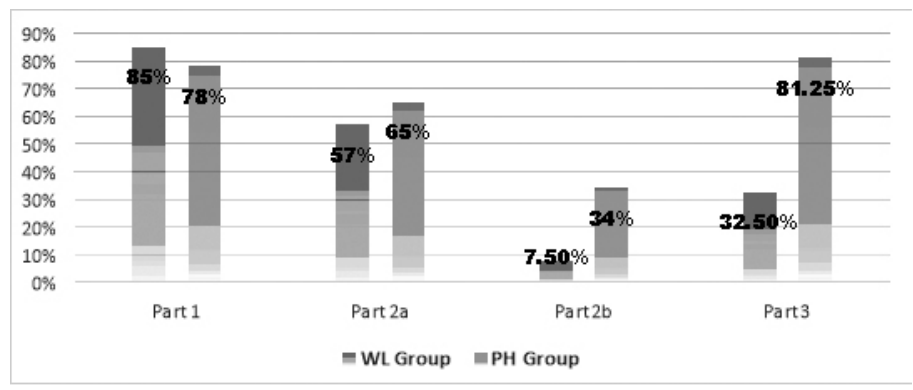

Table 2 - Test accuracy rates

The interviews, on the other hand, provided an interesting insight in why the participants decided to take part in a literacy course and their 
attitudes towards it. The participants gave these as their top three reasons for taking up the course - becoming literate would give them sense of independence; it would make them feel better about themselves; it would enable them to be more involved in their children's schoolwork. Even though nearly all the participants did get verbal support from their families (except S3 and S5 whose husbands supported them, but not their parents), the support was missing in the case of female participants when the words were to be put into action. Although their husbands had the possibility to take on some housework so that the women could study more at home, the men did not break the traditionally given roles. The aforementioned only highlights the significance of sociocultural factors in learning process, which unfortunately, do not get nearly as much attention as "more linguistic" factors such as metalinguistic awareness, L1 literacy etc.

If we take both results of the test and interview into consideration it is clear that both approaches have advantages and disadvantages. Although natural, functional language is used, that has immediate practical application, the whole language approach is not systematic enough. Phonics-based curriculum uses relevant materials with appropriate content, easy to decode which is of the utmost importance when teaching languages with opaque orthography. Although the results of the test showed that $\mathrm{PH}$ group made better overall progress, according to the interviews WL group felt that they made greater progress. Subjective feeling of progress is not to be underestimated. It serves as strong motivational force, especially in L2 literacy courses. This feeling of progress directly stems from the type of materials used. Students can see the words they learnt in class in everyday life. Despite the efficiency of the phonics-based approach, students found materials to be somewhat boring and uninspiring. Also, three out of four of them stated that they sometimes felt as if they were children, unlike none in the WL group.

Therefore the most efficient and effective is to use a combination of the two. The focus should be on phonics, but with some materials which rely on whole language approach, meaning functional language, which will give students this subjective feeling of progress which is especially important for literacy classes.

\section{Conclusion and Implications for future research}

If a learner has even the lowest level of L1 literacy, it will facilitate L2 literacy acquisition. The learner will understand basic reading and writing 
concepts (e.g. what a written word represents, that written language is a system etc.). Additionally, learners who possess some degree of literacy, have usually undergone some form of formal education (public schools, religious schools, in-camp lessons etc.). Formal schooling will not only be important due to the fact that such learners are familiar with the concept of school and classes, but also the fact that they had metalinguistic training and therefore possess certain degree of metalinguistic awareness. Moreover, they might have explicit learning mechanisms that can compensate for implicit (such as age) if necessary. Also, sociocultural factors are of invaluable practical importance when selecting culturally sensitive materials and developing curriculum.

Teaching L2 literacy courses is quite challenging for teachers, but at the same time it can be motivating. Having in mind the sheer number of learners who are in need of this kind of course, further and more extensive research of factors and processes involved in gaining L2 literacy skills in general is needed in order to not only develop contemporary curriculums, programs and materials, but also teacher training programs.

\section{References}

August, D. (2003). Supporting the development of English literacy in English language learners - Key issues and promising practices. Baltimore/USA: CRESPAR

Benseman, J. (2012). Adult refugee learners with limited literacy: needs and effective responses. New Zealand: Ako Aotearoa.

Bigelow, M. \& Watson, J. (2012). The role of educational level, literacy, and orality in L2 learining. In: The Routledge Handbook of Second Language Acquisition (S. Gass \& A. Mackey, eds). London/New York: Routledge, 461-475.

Birch, B.M. (2002). English L2 reading: Getting to the bottom. Mahwah/ NJ: Lawrence Erlbaum Associates.

Burt, M., Peyton, J.K., \& Adams, R. (2003). Reading and adult English language learners: A review of a research. Washington, DC: Centre for Applied Linguistics.

Coady, J. (1997). L2 vocabulary acquisition through extensive reading. In: Second language vocabulary acquisition (J. Coady \& T. Huckin eds.), Cambridge/England: Cambridge University Press, 225-237. 
Condelli, L. \& Wrigley, H.S. (2008). The What Works Study: Instruction, Literacy and Language Learning for Adult ESL Literacy Students. In: Tracking Adult Literacy and Numeracy Skills: Findings from Longitudinal Research (S. Reder \& S. Bynner eds.), London \& New York: Routledge.

Goldberg, R. (1997). Deconstructing the great wall of print. Connections: A Journal of Adult Literacy, 1, 8-13.

Gombert, J. E. (1992). Metalinguistic Development. London: Harvestern Wheatsheaf.

Goodman, K.S. (1967). Reading: A psycholinguistic guessing game. Journal of reading Specialist 6, 126-135.

Gough, P.B. (1972). One second of reading. In: Language by ear and by eye (J Metsala \& L.C. Ehri eds.), Mahwah/NJ: Erlbaum, 209-232.

Grabe, W., \& Stoller, F.L. (2002). Teaching and researching reading. Harlow/ England: Pearson Education.

Gunn, M. (2003). Opportunity for literacy? Preliterate learners in the AMEP. Prospect, 18 (2), 37-53.

Huntley, H.S. (1992). The new illiteracy: A study of the pedagogic principles of teaching English as a second language to non-literate adults. Unpublished manuscript. (ERIC Document Reproduction Service No. ED 356 65).

Klassen, C., \& Burnaby, B. (1993), „Those who know“: Views on literacy among immigrants in Canada. TESOL Quarterly, 27, 377-397.

Kodžopeljić, J. (1996). Metalingvistički preduslovi uspešnog usvajanja čitanja. Psihologija, 1, 35-48.

Rayner, K. et al. (2002). How should reading be taught? Scientific American 286, 84-91.

Reder, S. \& Davila, E. (2005). Context and literacy practices. Annual Review of Applied Linguistics, 25, 170-187.

Strucker, J. (1997). What silent reading tests alone can't tell you: Two case studies in adult reading differences. Focus on Basics, 1(B), 13-17.

Statistical office of the republic of Serbia (2001). Stanovništvo staro 15 i više godina prema nacionalnoj pripadnosti, starosti, polu i školskoj spremi, po regionima - izveštaj. [online] Retrieved from http://www.stat.gov.rs/ sr-latn/oblasti/popis/popis-2011/popisni-podaci-eksel-tabele/ $\left[25^{\text {th }}\right.$ July 2018]

Treiman, R. (2017). Linguistics and reading. In: Blackwell handbook of linguistics (M. Aronoff \& J. Rees-Miller eds.) Oxford, England: Blackwell, 617-626.

Young-Scholten, M. \& Strom, N. (2006). First time L2 readers: Is there a critical period? In: Low-Educated Second Language and Literacy Acquisition: Proceedings of the Inaugural Symposium - Tilburg 05 (I. Van de Craats, J. Kurvers \& M. Young-Scholten eds.), Utrecht/The Netherlands: LOT, 45-68. 


\section{Mina Suknović}

\section{USVAJANJE VEŠTINE ČITANJA NA STRANOM JEZIKU OD STRANE NEPISMENIH ODRASLIH, MATERNJIH GOVORNIKA ARAPSKOG JEZIKA}

Sažetak: Mnoštvo faktora mora biti uzeto u obzir kada govorimo o usvajanju veštine čitanja na stranom jeziku kod nepismenih odraslih - kognitivni procesi, sociokulturne razlike, afektivna stanja, traume, nepoznata okruženja poput učionice itd. Rad se ipak fokusira na kognitivne procese i njihove implikacije, kako bi se razvile prikladne strategije za rad sa polaznicima tog profila. U radu se pored uzlaznih i silaznih procesa, ističe i važnost fonološke svesti. Stručnjaci se generalno slažu da metalingvistička svest, a fonološka pogotovo, ima ulogu facilitatora prilikom usvajanja čitanja. S druge strane, postojanje najbazičnijih veština čitanja i pisanja omogućava razvijanje fonološke svesti. Stoga je važno razviti programe koji istovremeno razvijaju receptivne i produktivne veštine, kao i fonološku svest. Takođe, rad preispituje efikasnost fonetskog pristupa i pristupa koji počiva na usvajanju celih jezičkih jedinica koristeći rezultate studije koja je pratila nepismene odrasle polaznike, govornike arapskog jezika, tokom tri meseca na kursu opismenjavanja na engleskom jeziku. Na osnovu rezultata studije primećeno je da oba pristupa imaju određene prednosti i mane, ali da je ipak najefikasnije kombinovati ih, $\mathrm{s}$ tim što prednost treba dati fonetskom pošto je krucijalan za razvijanje fonološke svesti. Iako je odnos fonološke svesti i usvajanja čitanja pomalo kao odnos kokoške i jajeta, većina istraživanja, ovo takođe, ističe važnost razvijanja fonološke svesti i postojanja sistematičnog pristupa usvajanju čitanja.

Ključne reči: veština čitanja, L2 pismenost, fonološka svest, uzlazni i silazni procesi, fonetski pristup, usvajanje celih jezičkih jedinica 